San Jose State University

SJSU ScholarWorks

Master's Theses

Master's Theses and Graduate Research

Spring 2013

\title{
A Pilot Program To Evaluate the Effect of Training Table-Based \\ Nutrition Education and Menu Modification on the Nutrition \\ Knowledge and Dietary Intake of Collegiate Football Players at a \\ NCAA Division I University
}

Rida Wali

San Jose State University

Follow this and additional works at: https://scholarworks.sjsu.edu/etd_theses

Recommended Citation

Wali, Rida, "A Pilot Program To Evaluate the Effect of Training Table-Based Nutrition Education and Menu Modification on the Nutrition Knowledge and Dietary Intake of Collegiate Football Players at a NCAA Division I University" (2013). Master's Theses. 4320.

DOI: https://doi.org/10.31979/etd.jtq3-ze2c

https://scholarworks.sjsu.edu/etd_theses/4320

This Thesis is brought to you for free and open access by the Master's Theses and Graduate Research at SJSU ScholarWorks. It has been accepted for inclusion in Master's Theses by an authorized administrator of SJSU ScholarWorks. For more information, please contact scholarworks@sjsu.edu. 


\title{
A PILOT PROGRAM TO EVALUATE THE EFFECT OF TRAINING TABLE-BASED NUTRITION EDUCATION AND MENU MODIFICATION ON THE NUTRITION KNOWLEDGE AND DIETARY INTAKE OF COLLEGIATE FOOTBALL PLAYERS AT A NCAA DIVISION I UNIVERSITY
}

\author{
A Thesis \\ Presented to \\ The Faculty of the Department of Nutrition, Food Science and Packaging \\ San José State University \\ In Partial Fulfillment \\ of the Requirements for the Degree \\ Master of Science
}

by

Rida Wali

May 2013 
(C) 2013

Rida Wali

ALL RIGHTS RESERVED 
The Designated Thesis Committee Approves the Thesis Titled

A PILOT PROGRAM TO EVALUATE THE EFFECT OF TRAINING TABLE-BASED NUTRITION EDUCATION AND MENU MODIFICATION ON THE NUTRITION KNOWLEDGE AND DIETARY INTAKE OF COLLEGIATE FOOTBALL PLAYERS AT A NCAA DIVISION I UNIVERSITY

by

Rida Wali

APPROVED FOR THE DEPARTMENT OF NUTRITION, FOOD SCIENCE AND PACKAGING

SAN JOSÉ STATE UNIVERSITY

May 2013

Dr. Clarie B. Hollenbeck Department of Nutrition, Food Science and Packaging

Elizabeth Brown Department of Nutrition, Food Science and Packaging

Ashwini Wagle Department of Nutrition, Food Science and Packaging 


\title{
ABSTRACT
}

\section{A PILOT PROGRAM TO EVALUATE THE EFFECT OF TRAINING TABLE- BASED NUTRITION EDUCATION AND MENU MODIFICATION ON THE NUTRITION KNOWLEDGE AND DIETARY INTAKE OF COLLEGIATE FOOTBALL PLAYERS AT A NCAA DIVISION I UNIVERSITY}

\author{
by Rida Wali
}

Due to nutrition-related knowledge misconceptions, undesirable dietary choices, and risk of developing obesity-related chronic diseases, nutrition intervention is strongly recommended for collegiate football players. For the present study, nine players completed the protocol as designed while three were self-selected controls. Nutrition knowledge was evaluated at baseline and at the end of the study. Food intake was analyzed over 3-weeks during three study periods: baseline (2 days) which consisted of observation only, nutrition education (1 day) which consisted of a 1-hour guided discussion, and combination treatment ( 2 days) which consisted of continued nutrition education at the training table along with the addition of fresh fruit and $1 \%$ chocolate milk to the training table menu. All subjects had access to the same meals, but the control group did not receive any nutrition education. A Wilcoxon signed rank test was used to analyze differences in knowledge and food intake. Results indicated that the nutrition education intervention significantly increased nutrition knowledge in the intervention group $(p=0.018)$. Similarly, combination treatment significantly increased intake of fresh fruit and $1 \%$ chocolate milk in the intervention group only $(p=0.008)$. Therefore, the training table may be a viable and an inexpensive avenue for improving nutrition knowledge and diet quality of athletes. 


\section{ACKNOWLEDGEMENTS}

This thesis is dedicated to my daughter, Amani, and to the many individuals whose support enabled me to achieve this milestone.

S.M. Khalid, my dear grandfather, how I wish you were alive to see this day. Your knowledge, wisdom, and home-made bread instilled a love for food and nutrition in me which has led to this career choice. I miss you so much.

Farnaz and Sabih, my loving parents, thank you for supporting me, believing in me, and for letting me dream. Surely, none of this would have been possible without you. Your love, selflessness, and untiring spirit assure me that anything is possible, and that the love of a parent knows no bounds.

Fahad, my infinitely patient husband, words cannot express how much you mean to me. Your love and support were truly the backbone upon which I was able to complete this work. I could not have done this without you. Thank you.

Clarie, Izzie and Ashwini, you have been amazing teachers, friends, and mentors. You have touched so many lives with your wisdom and knowledge. The Nutrition, Food Science and Packaging Department at San José State University is incredibly lucky to have such dedicated teachers like you. Of course, this thesis would have been impossible without you. Thank you.

Circle of Friends - Department of Nutrition, Food Science and Packaging, San José State University football team, Scott Shaw, Bryan McGinnis, Mike MacIntyre, Jennifer Waldrop, and Daniel Ybarra, thank you for your support for this research, it was truly a pleasure to work with you.

Janelle Estournes, Michelle Stroebe, Erin Hodgson, and Sophie Snook, thank you so much for your help with the data collection for this thesis. 


\section{PREFACE}

The following is a publication style thesis. Chapters I and III are written according to the guidelines outlined in the Publication Manual of the American Psychological Association, 6th edition, 2010. Chapter II is written in journal format according to the guidelines of the Journal of the Academy of Nutrition and Dietetics, Research and Professional Briefs section. 


\section{TABLE OF CONTENTS}

Page

List of Figures $\quad$ X

List of Tables $\quad$ xi

$\begin{array}{ll}\text { Introduction } & 12\end{array}$

$\begin{array}{ll}\text { CHAPTER I: Review of Literature } & 14\end{array}$

Review of Literature $\quad 15$

$\begin{array}{ll}\text { Definition } & 15\end{array}$

$\begin{array}{ll}\text { American Football } & 15\end{array}$

NCAA and Intercollegiate Athletics 15

$\begin{array}{ll}\text { Collegiate Football Players } & 17\end{array}$

$\begin{array}{ll}\text { Nutrition Knowledge and Dietary Practices } & 17\end{array}$

$\begin{array}{ll}\text { Physiological Profiles } & 21\end{array}$

Health Risks Associated with Anthropometric Characteristics 23

Role of the Collegiate Athletic Staff 25

Nutrition Support Programs for Collegiate Athletes 27 
Change in Food Intake

Change in Beverage Intake

Limitations

References 


\section{LIST OF FIGURES}

Page

Figure 1. Study timeline for a training table based nutrition education

39

and menu modification intervention in collegiate football

players at a NCAA Division I university 


\section{LIST OF TABLES}

Page

Table 1. Nutrition knowledge scores of collegiate football players at a Division I university pre- and post-study

Table 2. Food and beverage intake of collegiate football players at a NCAA Division I university at baseline, nutrition education and combination periods 


\section{Introduction}

Collegiate football is a popular sport in the United States that brings in revenue for many institutions, particularly through media rights payments. Therefore, it is reasonable to presume that collegiate football players are under intense pressure to perform well and may resort to unsubstantiated nutritional practices to maximize

performance. Inadequate nutrition knowledge (Jonnalagadda, Rosenbloom, \& Skinner, 2001), undesirable dietary practices (Cole et al., 2005; Jonnalagadda et al.; Kirwan et al., 2012), and prevalence of obesity, dyslipidemia, and metabolic syndrome (Buell et al., 2008; Jonnalagadda et al.; Kaiser et al., 2008; Kirwan et al.; Wilkerson, Bullard, \& Bartal, 2010) have been reported in collegiate football players, thus placing them at risk for developing obesity-related chronic health conditions. Furthermore, the prevalent culture of attaining and maintaining large body dimensions amongst football players warrants the need for timely dietary intervention. Therefore, nutrition education and intervention are strongly recommended in this population (Buell et al.; Cole et al.; Jonnalagadda et al.; Kirwan et al.).

Although appropriate nutrition knowledge is a prerequisite for behavior change, food choices of collegiate athletes are further dependent on availability of time and accessibility to nutritious food (Heaney, O’Connor, Naughton, \& Gifford, 2008; Long, Perry, Unruh, Lewis, \& Stanek-Krogstrand, 2011). Therefore, effective nutrition intervention for athletes must acknowledge time and accessibility to nutritious foods as limiting factors to dietary changes independent of nutrition education. 
Due to frequency of contact, members of the athletic staff, such as athletic trainers, strength and conditioning specialists, and coaches are ideally positioned to influence the dietary habits of collegiate football players. However, since nutrition is not the primary focus of the athletic staff and many do not possess accurate knowledge, access to a professionally trained nutrition expert such as a registered dietitian (RD) may be warranted (Burns, Schiller, Merrick, \& Wolf, 2004; Heaney et al., 2008; Quatromoni, 2008; Smith-Rockwell, Nickols-Richardson, \& Thye, 2001; Torres-McGhee et al., 2012).

The fact that athletes rely on the athletic staff for nutritional guidance and that time and accessibility to nutritious foods is a concern for many athletes, the training table, which is a meal provided to athletes by the athletic staff, may be a viable option for nutrition education and dietary intervention of collegiate football players. By providing nutrition education while athletes eat and using the meal being consumed as a bench mark for recommended nutritional practices, training table-based nutrition education fulfills multiple purposes. Currently, there is no training table-based nutritional intervention evaluated in the literature. Therefore, the purpose of the present study was to evaluate the role of training table-based nutrition education and menu modification on the nutrition knowledge and dietary intake of collegiate football players at a NCAA Division I university. 
CHAPTER I

REVIEW OF LITERATURE 


\section{REVIEW OF LITERATURE}

\section{Definition}

Training table - A meal regularly provided to athletes by the athletic staff. For the purposes of the present study, the training table refers to an after practice lunch meal that was provided to the San José State University football team. Team members on scholarship (90 players) inclusive of the study participants ate from the same buffet-style, self-serve food stations.

\section{American Football}

American football is a fast paced game requiring strength, speed, and power (Hoffman, 2008). It utilizes both the aerobic and anaerobic energy systems therefore utilizing carbohydrate and fat as primary fuel sources (Bonci, 2009). Each game consists of four 15-min quarters with a 20-min half-time break; however, actual duration of the game is much longer due to breaks between plays. At any time during a game, there are 11 players from each team actively playing on the field. The game requires multiple specialized positions that have different offensive or defensive responsibilities. Depending on the position, players vary in anthropometric characteristics. Generally, linemen tend to be the largest players on the team while other positions require different combinations of strength, speed, and power.

\section{NCAA and Intercollegiate Athletics}

The National Collegiate Athletic Association (NCAA) is a non-profit organization that governs the involvement of athletes in institutions of higher education across the United States. The majority of its revenue comes from media rights payments, an 
estimated $\$ 777$ million for the year 2011-2012. Of that revenue, $60 \%$ is used to support Division I athletic programs and 13\% is used to support 89 championships in 23 sports (National Collegiate Athletic Association, n.d.).

As reported by Fulks (2012), institutions are grouped into one of three major NCAA subdivisions. Division I Football Bowl Subdivision (FBS, formerly known as Division I-A) includes institutions that play $60 \%$ or more of their regular season football games against other FBS institutions. In addition to other specifications, these institutions must adhere to specific requirements for attendance and scheduling of games and financial aid to athletes. Division I Football Championship Subdivision (FCS, formerly known as Division I-AA) institutions are required to play more than $50 \%$ of their regular season football games against FBS or FCS institutions. In addition to other specifications, these institutions must adhere to specific requirements for scheduling and financial aid. Division II includes institutions that must play at least 50\% of all their football games against FBS, FCS, or Division II institutions. Although additional requirements exist, these institutions have no attendance, scheduling, or financial aid requirements. Division III includes institutions that must play more than $50 \%$ of football games against Division III teams or non-member institutions who grant need-based financial aid. Although additional requirements exist, these institutions have no attendance or scheduling requirements and athletic financial aid is not permitted. Men's football is the most popular and the lead revenue-generating sport for NCAA, followed by men's and women's basketball, respectively (Fulks, 2012). NCAA statistics indicate that in 2011, 638 collegiate football teams competed in 3,538 games 
that were attended by 49,699,419 spectators (National Collegiate Athletic Association, Football Attendance Records, n.d.).

Considering that much of the revenue generated by collegiate football teams is based on payments for media rights, teams that perform well and compete in conference bowl games are more likely to bode well financially. Due to the revenue-generating potential of the game, especially in Division I and II institutions, and athletic aspirations of playing in the National Football League, it is reasonable to presume that collegiate football players are under intense pressure to perform well. These reasons may have profound implications on the training and dietary practices of collegiate football players.

\section{Collegiate Football Players}

Nutrition Knowledge and Dietary Practices. It is generally believed that adequate nutrition is vital to overall health, peak performance, and recovery from physical activity. The joint position paper of the American College of Sports Medicine, Academy of Nutrition and Dietetics, (formerly known as the American Dietetic Association) and Dietitians of Canada (2009) recommended: “...appropriate selection of foods and fluids, timing of intake, and supplement choices for optimal health and exercise performance" (p. 709).

Several studies in the literature have evaluated the nutrition knowledge and dietary practices of collegiate football players. A better understanding of these practices will likely enable appropriate interventions for this population. Jonnalagadda et al. (2001) used a self-administered questionnaire to determine dietary habits and attitudes towards nutrition in 31 Division I freshman football players. These athletes reported 
eating 3.6 \pm 1 times per day, dined out $4.8 \pm 4.1$ times per week, and chose to eat at fast food restaurants and cafeteria or buffet style restaurants most often (55\% and $16 \%$ of the time, respectively). Only $3 \%$ of the athletes perceived their eating habits as poor, while the rest described them as fair (58\%) or good (39\%). Food restrictions such as avoidance of sweets, fried foods, fats, fast food, fish, dairy, and red meat were also reported. Overall, $42 \%$ of the athletes used supplements, with creatine being the most popular (36\%) followed by vitamins and minerals (23\%). In their study, Jonnalagadda et al. also reported a mean score nutrition knowledge of $5.55 \pm 1.72$ (out of 11), indicating a low level of knowledge and high prevalence of misconceptions regarding the role of macronutrients, micro-nutrients, supplements, and hydration practices. More than $50 \%$ of the athletes believed that protein was the main energy source for muscles and that protein supplements were necessary. Some of these athletes desired changes in body composition including increased lean body mass, decreased body fat, and weight loss. They also expressed a strong interest in obtaining information on nutrition for optimal performance, weight gain, and tips on eating out. Based on their results, Jonnalagadda et al. strongly recommended performance-related nutrition education in collegiate football players.

To evaluate dietary patterns of football players, Cole et al. (2005) collected two sets of 3-day diet records from 28 Division I freshmen football players and compared them to calculated needs using age and gender matched groups from the Third National Health and Nutrition Survey (NHANES III). Overall, the football players consumed significantly fewer calories than the estimated 4000-5300 kcals per day required to 
sustain their activity levels. Furthermore, the dietary patterns of the subjects did not follow USDA guidelines of recommended servings per day especially for the fruit and vegetable groups. Consumption of fruits and vegetables was 1.6 and 1.3 servings per day, respectively, compared to the recommended 2-4 and 3-5 servings per day, respectively. Consumption of fats, oils, and sweets was 16.4 servings per day (recommended sparingly). Furthermore, five of the athletes also reported avoiding fruit and bread products in order to achieve weight loss by restricting carbohydrates. Based on their findings, Cole et al. concluded that nutrition education and intervention were warranted in this population to dispel misinformation and plan diets appropriate to sustain required activity levels.

Kirwan et al. (2012) analyzed 3-day pre- and post-season diet records over an 8week period in 15 Division I freshmen football players who ate at university dining facilities. At the end of the study period, participants had significantly increased total energy (45\%), carbohydrate (82\%), and protein (29\%) intake with no changes in fat intake. Results indicated that both, the pre- and post-season diet was low in dietary fiber $(18,19 \pm 8 \mathrm{~g} /$ day, respectively) and high in fat and cholesterol which was consistent with high intakes of dairy, meat, and cheese. Results of this study highlight the fact that players increase food consumption due to increased energy expenditure but may not necessarily make the appropriate food choices.

Long et al. (2011) developed a theoretical model to describe the food-related behaviors of Division II football players. They used the "personal food choice process" which is defined as "the set of procedures used for making food choices, including the 
weighing and balancing of activities of daily life, physical well-being, convenience, monetary resources and social relationships" (p. 688) to develop their model. Based on interviews with 15 Division II football players representing various positions on the team, limited time was identified as the main factor influencing food-related decisions. Additionally, athletes reported protein as the main nutrient of concern and preferred consuming quick-fix meals items that they considered healthful such as fruits, vegetables, lean beef, and chicken. Some athletes commented that they were influenced by what their peers ate, while others reported that the diet of their peers had no influence on their food choices. Furthermore, these athletes reported having limited access to nutrition support services and being overwhelmed by food choices at the college cafeteria. Since Division II athletes are responsible for procuring their own meals, these results may not be applicable to football players or athletes who have different access to food and nutrition support staff. However, they do provide valuable insight on potential influences on dietary choices of collegiate football players.

Similarly, lack of time (for food purchasing and preparation) was identified as the primary barrier to optimal nutrition by a focus group of 46 elite Australian athletes (age range 16-45 years) from a variety of sports (Heaney et al., 2008). Other factors included monetary constraints and limited access to nutritious food due to limited availability in areas where athletes spent most of their time (residence halls and practice facilities). The study also included opinions of 12 coaches and 16 dietitians who identified lack of nutrition knowledge as a barrier to consumption of healthful foods. Therefore, these 
investigators suggested that limited time should be recognized as a barrier when planning nutrition support for athletes.

Physiological Profiles. Due to the nature of football, large body sizes, which can execute quick and powerful movements and withstand tackles, are favored; thereby creating a predominant culture of attaining and maintaining large body proportions. However, being overweight or obese, having excess fat mass or an abnormal lipid profile are known risk factors for chronic health conditions such as type 2 diabetes and cardiovascular disease (CVD). Several studies have identified collegiate football players being at risk of developing obesity-related chronic health conditions which may warrant timely dietary intervention.

In a sample of 31 Division I collegiate football players, Jonnalagadda et al. (2001) reported a group mean body mass index (BMI) of $27.6 \mathrm{~kg} / \mathrm{m}^{2}$ and a BMI of $33.1 \mathrm{~kg} / \mathrm{m}^{2}$ for linemen in the group. Furthermore, seven of the 31 athletes had total cholesterol values above the recommended value of $200 \mathrm{mg} / \mathrm{dL}$ with offensive linemen having the highest values. Similarly, Kirwan et al. (2012) reported a BMI of $26.6 \pm 3.4 \mathrm{~kg} / \mathrm{m}^{2}$ in 15 Division I freshmen football players. Body composition using DEXA scans revealed increased fat and muscle mass over an 8-week season with an average weight gain of 3kg. Furthermore, post-season blood lipid evaluation indicated increased total cholesterol and low-density lipoprotein cholesterol levels when compared to pre-season values. Kirwan et al. concluded that increased body mass was due to gains in both muscle and fat mass with gains in the latter being a known risk factor for CVD. They recommended dietary supervision for appropriate weight gain without adversely affecting the lipid 
profile of these athletes. Large body size, high fat mass, and above normal blood lipid values are known risk factors for developing obesity-related chronic diseases. Therefore, detection of these risks and early nutritional intervention may be warranted.

Several studies have indicated the presence of metabolic abnormalities in collegiate football players. In a sample of 62 Division I football players, Wilkerson et al. (2010) reported that 12 (19\%) players presented with metabolic syndrome, 35 (57\%) had high blood pressure, 11 (18\%) had high triglyceride levels, 15 (24\%) had low highdensity lipoprotein cholesterol levels, and 18 (29\%) had high fasting blood glucose levels. Overall, 49 out of the $62(79 \%)$ players had an above normal value for at least one of the diagnostic components of metabolic syndrome. Players identified with metabolic syndrome had a BMI of $31.9 \pm 5.8 \mathrm{~kg} / \mathrm{m}^{2}$, mean body fat percentage of $19.5 \pm 8.8 \%$, significantly lower high-density lipoprotein cholesterol levels, and significantly higher waist circumference, blood pressure, total cholesterol, triglyceride, and fasting plasma glucose levels than those without metabolic syndrome. Based on their findings, Wilkerson et al. (2010) concluded that due to their high risk of developing metabolic syndrome, collegiate football are at a high risk for developing type 2 diabetes and CVD, and should be provided with support for developing healthy dietary behaviors. Similarly, in a sample of 70 linemen from Division I, II, and III schools, Buell et al. (2008) identified 34 athletes with metabolic syndrome; 12 had total cholesterol levels greater than $200 \mathrm{mg} / \mathrm{dL}$. Furthermore, athletes in Division I were taller and heavier than Division II athletes who were taller and heavier than Division III athletes, indicating that placement in a NCAA division may influence the dietary and physical activity habits of 
athletes (Buell et al., 2008). Due to the high prevalence of biomarkers indicating metabolic syndrome, Buell et al. recommended early dietary and lifestyle interventions in collegiate football players.

Health Risks Associated with Anthropometric Characteristics. Collegiate football players with comparable anthropometric values to professional football players (Kaiser et al., 2008) may indicate an alarming trend in the development of obesity-related disease risk in these young athletes. In a retrospective evaluation of 3,439 NFL players, Baron, Hein, Lehman, and Gersic (2012) reported risk factors associated with CVDrelated mortality. Players with a BMI of greater than or equal to $30 \mathrm{~kg} / \mathrm{m}^{2}$ were twice as likely to die of CVD than other players. Defensive linemen had $42 \%$ greater mortality due to CVD compared to the general male population in the United States, and AfricanAmerican players were at higher risk of CVD-related mortality than Caucasian players. Therefore, it is reasonable to assume that collegiate football players with similar anthropometric profiles as professional football players may be at a similar risk for developing CVD. Even though BMI does not distinguish between lean or fat mass, with the latter being a risk factor for obesity-related chronic disease, these results indicate that BMI may still be a useful indicator of health risk in football players. Although CVDrelated mortalities have not been reported in collegiate football players, several studies have described anthropometric and metabolic profiles of collegiate football players which suggest that their disease risk may be similar to that of professional football players.

Kaiser et al. (2008) reported that in a sample of 65 freshman football players, offensive and defensive linemen had the highest body fat percentages and BMI. Based 
on BMI, the players would be classified as overweight or obese. However, based on body fat percentage, they fell within acceptable age and gender matched ranges. Although the morphological profiles of players in this study did not indicate any specific health risks, when compared to data on professional football players (Kraemer et al., 2005), athletes in this subset had the same body weight, had $1 \%$ more body fat, had similar BMI values and were $1 \mathrm{~cm}$ taller. The finding that this subset of players in the early years of their career had comparable anthropometric values as professional players might be indicative of the trend of selecting taller and heavier football players by teams. This may have consequences for future health risks of these young athletes as they progress in their careers (Kaiser et al., 2008).

In a retrospective analysis, Jacobson (2012) analyzed anthropometric data of Division I collegiate football players over seven decades, from 1950 to 2010 . Height and weight comparisons were performed on data from 1,344 linemen and 930 wide receivers and defensive backs. Both defensive and offensive linemen experienced an average weight gain of $7.5 \mathrm{~kg}$ per decade and height increased by $5.08 \mathrm{~cm}$ and $1.8 \mathrm{~cm}$ per decade, respectively. However, wide receivers and defensive backs experienced minimal changes in height and weight. Although the author did not evaluate the composition of weight gain, increased muscle mass may have accompanied increased body fat which is a known risk factor for CVD. Therefore, Jacobsen (2012) recommended that players of larger proportions, especially linemen may need nutrition counseling to maintain a healthy lifestyle. 
In a similar study, Anzell, Potteiger, Kraemer, and Otieno (2013) reported that between 1942 and 2011, collegiate football players at all positions significantly increased in body weight. Weight increase was $0.338-0.9 \mathrm{~kg} / \mathrm{year}$ in linemen, $0.089-0.298 \mathrm{~kg} / \mathrm{year}$ in offensive backs, and 0.078-0.334 kg/year in defensive backs and wide receivers. Additionally, linemen also experienced statistically significant increases in height and body fat percentage $(0.034-0.188 \mathrm{~cm} /$ year and $0.046-0.275 \% / y e a r$, respectively). Anzell et al. suggested that these changes were a result of targeted physical training by teams to increase body size, increased prevalence of athletic trainers and coaches on collegiate staff, improved nutritional intake, intake of performance enhancing substances, and rule changes such as no blocking below the waist which has favored the selection of larger and stronger players for the linemen positions.

Increased overall size, reported deficits in knowledge, undesirable eating practices, and altered physiological health indicators all highlight the susceptibility of collegiate football players for developing obesity and obesity-related chronic conditions. It is imperative that athletic staff members acknowledge the ramifications of these changes and consider the role of nutrition education and interventions on the current health and future well-being of these athletes.

\section{Role of the Collegiate Athletic Staff}

Collegiate athletes have frequently identified members of the athletic staff (coaches, strength and conditioning specialists, and athletic trainers) as a source of nutrition knowledge (Burn et al., 2004; Jacobson, Sobonya, \& Ransone 2001; Parr, Porter, \& Hodgson 1984; Torres-McGhee et al., 2012). However, the accuracy of 
nutrition knowledge of these staff members is inconsistent; athletic trainers and strength and conditioning specialists have been shown to possess better nutrition knowledge than coaches, and access to a registered dietitian or a sports nutrition professional may be warranted for reliable nutrition-related information (Burns et al.; Heaney et al., 2008; Quatromoni, 2008; Smith-Rockwell et al., 2001; Torres-McGhee et al.).

Studies evaluating the nutrition knowledge of athletic staff members are detailed in this section. Corley, Demarest-Litchford, and Bazzarre (1990) reported a mean nutrition knowledge score of $70 \%$ by 175 college coaches in North Carolina representing a variety of sports. However, only $33 \%$ of the coaches were confident in their answers. Health books were reported as the main source of nutrition-related knowledge and only $2 \%$ of coaches used registered dietitians as a source of information. Smith-Rockwell et al. (2001) reported that in a sample of 35 coaches and 18 athletic support staff from a Division I institution, the mean nutrition knowledge score was $67 \%$. Strength and conditioning coaches scored the highest (80\%) followed by athletic trainers $(66 \%)$ and then coaches $(62 \%)$. Participants did not have a full-time dietitian on staff and popular magazines were the most frequently reported source of nutrition information. Shifflett, Timm and Khanov, (2002) reported that from a sample of 98 athletic trainers and 68 coaches from Division I, II and III institutions, athletic trainers correctly responded to $74 \%$ of nutrition-related questions while coaches correctly responded to $64 \%$ of the questions. Participants who scored $80 \%$ or more (24 athletic trainers, 8 coaches), reported that their most frequently used sources of nutrition information were academic journals, nutrition faculty, and college-level nutrition and health-related courses. 
Recently, Torres-McGhee et al. (2012) reported that in a sample of 192 athletic trainers, 131 coaches, and 71 strength and conditioning specialists from Division I, II, and III institutions, the athletic trainers and strength conditioning specialists had the highest mean knowledge scores, $77.8 \%$ and $81.6 \%$, respectively. Furthermore, both athletic trainers and strength and conditioning specialists reported using academic journals and registered dietitians as the top two sources of nutrition information. Additionally, 169 $(50.1 \%)$ of these athletic departments reported having a full-time or part-time registered dietitian available for athletes while the other 168 (49.9\%) departments reported having access to a dietitian in the student health center or through off-campus private practice (Torres-McGhee et al., 2012).

Since the athletic staff, including coaches, athletic trainers, strength and conditioning specialist, and registered dietitians in some cases, have extensive interaction with collegiate athletes, they may be ideally positioned to influence dietary habits in this population. However, since the coaching staff has multiple duties and not all of the staff members have the same level of nutrition knowledge; collaboration with a registered dietitian may best serve the nutritional needs of athletes (Smith-Rockwell et al., 2001; Burns et al., 2004; Heaney et al., 2008; Torres-McGhee et al., 2012).

\section{Nutrition Support Programs for Collegiate Athletes}

Recognizing the importance of nutrition for athletic performance and recovery, several collegiate institutions across the country have implemented nutrition support programs. Clark (1994) outlined the creation of the nation's first sports nutrition position at Penn State University. Established in 1985 as a part-time position, the role of a sports 
nutritionist evolved into a faculty position as the Director of Sports Nutrition. By 1994, the Director served 1000 athletes in 28 varsity sports teams with duties in the areas of nutrition counseling, education, administration, and collaboration with the food service and athletic staff. Clark further reported the use of a system of red, yellow, and green colored dots to mark foods of different fat content at three training tables. Based on an athlete survey, this system resulted in athletes selecting lower fat foods and more fish, fruits, and vegetables. Due to the success of the intervention, the coding system was implemented in nine dining halls across campus to promote healthy eating throughout the entire student body. Although the results seemed promising, Clark did not provide additional information regarding the intervention and survey methodology. Therefore, it is difficult to conclude whether the intervention resulted in substantial changes in the dietary patterns of athletes or the student population at Penn State.

Other studies have also reported on the importance of nutrition support services for collegiate athletes. Vinci (1994) described the role of a sports nutritionist at University of Washington. The nutritionist served multiple duties including those of nutrition counseling, education, and administration while being a vital part of a multidisciplinary health team committed to the well-being of athletes. However, no training table specific interventions were mentioned. Quatromoni (2008) also emphasized the role of a sports dietitian/nutrition consulting service as being an integral part of a multidisciplinary health team to screen and assess athletes, provide nutrition counseling and education, and enable athletes to build self-efficacy towards healthful eating habits. 
While evidence exists that a dietitian or nutrition services are valuable to an athletic department, evidence regarding the dietary intake of athletes at a training table beyond that published by Clark (1994) is not available. This could be due to lack of scientific publications or due to lack of such data collected. Nonetheless, many athletic departments offer a training table which may be an untapped avenue for providing nutrition education and intervention. By serving nutritious food items, the training table can set an example of what the athletes should be consuming at eating occasions beyond the training table. Furthermore, by providing nutrition education through a recognized specialist in nutrition during the training table meal, no further time commitment is required by the athletes or the athletic staff to discuss basic nutritional concerns. Overall, the training table may be used as an avenue for fulfilling multiple health and nutritionrelated needs of collegiate athletes.

\section{CONCLUSION}

Due to the revenue generating potential of collegiate football, players may be under intense performance pressures which may in turn negatively impact their dietary choices. Furthermore, the prevalence of increased body size, obesity, fat mass, dyslipidemia, and metabolic syndrome places collegiate football players at risk for developing obesity-related chronic conditions. Therefore, timely nutrition education and intervention to promote health and maximize performance is strongly recommended in this population.

Factors that may influence the dietary choices of collegiate football players include but are not limited to: level of nutrition knowledge, availability of time to shop 
for and prepare meals, time management, financial status, peers, and the athletic staff (Burns et al., 2004; Jacobson et al., 2001; Parr et al., 1984; Torres-McGhee et al., 2012). Since the athletic staff has extensive interaction with athletes, they may be ideally positioned to positively influence dietary behavior. Therefore, meals provided by the athletic staff can serve as a model for dietary practices and an avenue for nutrition intervention of collegiate football players. A well-planned training table combined with nutrition education may not only provide athletes with knowledge but may also serve as a model for optimal nutritional practices at meals and snacks consumed outside the training table.

Based on this notion, the purpose of the present study was to evaluate the role of nutrition knowledge and training table menu modification on the nutrition knowledge and dietary intake of collegiate football players at a NCAA Division I university. 
Chapter II

JOURNAL ARTICLE 


\section{ABSTRACT}

Since collegiate football is a revenue generating sport for many institutions, it is likely that these athletes are under pressure to maximize performance and thus may resort to unsafe or unproven nutritional practices. Athletes lacking nutrition knowledge may not be able to adequately nourish themselves, which may negatively impact their performance and overall health. In the literature, it is indicated that the athletic staff is a source of nutrition knowledge for athletes. However, the training table - which is a meal provided by the athletic staff, has previously not been explored as an avenue for nutrition education and intervention. This study evaluated the effect of training table based nutrition education and menu modification in a sample of 12 collegiate football players. Nine completed the protocol as designed while three were self-selected controls. Food intake was analyzed over three weeks during the three study phases - baseline ( 2 days), nutrition education (1 day), and combination treatment (2 days). Performance-related nutrition education was provided to nine participants in a 1-hour guided discussion, group session and reinforced at the training table. Combination treatment included continued nutrition education with menu modification in the form of addition of fresh fruit and $1 \%$ chocolate milk to the menu. Addition of these items did not increase the food cost for the program. All subjects had access to the same meals but the control group did not receive any nutrition education. A Wilcoxon signed rank test was used to analyze intraindividual differences in knowledge and food intake. Results indicated that nutrition education significantly increased nutrition knowledge in the intervention group only $(P=$

0.018). Similarly, combination treatment significantly increased intake of fresh fruit and 
$1 \%$ chocolate milk in the intervention group only $(P=0.008)$. Therefore, the training table may be a viable and an inexpensive avenue for improving the nutrition knowledge and diet quality of athletes. 


\section{INTRODUCTION}

Collegiate football is a popular sport in the United States. In 2011, 638 National Collegiate Athletic Association (NCAA) football teams competed in 3,538 games across the nation, which were attended by 49,699,419 spectators (1). Since collegiate football is a revenue generating sport for many institutions, it is likely that these athletes are under intense pressure to perform well and may resort to unproven nutritional supplements or unsubstantiated dietary practices to maximize performance.

Although the importance of sound nutrition for athletic performance is welldocumented, collegiate football players do not seem to have the nutrition knowledge or appropriate dietary practices for optimal health and performance (2-4). It is reasonable to assume that athletes lacking nutrition knowledge may not be able to adequately nourish themselves.

Obesity, increased fat mass, dyslipidemia, and metabolic syndrome have all been reported in collegiate football players (2-4, 7-9). The trend of developing large body dimensions amongst football players $(5,6)$ has likely resulted in aberrant metabolic profiles, which compounded with a lack of nutrition-related knowledge and undesirable nutritional practices place collegiate football players at risk for developing chronic health conditions. Therefore, nutrition education and intervention is strongly recommended in this population $(2-4,8,9)$.

Although appropriate nutrition knowledge is a pre-requisite for behavior change, food choices of collegiate athletes are further dependent on availability of time and accessibility to nutritious food $(10,11)$. Therefore, effective nutrition intervention for 
athletes must acknowledge time and accessibility as limiting factors to dietary changes independent of nutrition education.

Collegiate athletes have frequently reported members of the athletic staff, such as athletic trainers, strength and conditioning specialists, and coaches, as their main source of nutrition information (12-14). Therefore, these staff members are ideally positioned to influence the dietary habits of collegiate football players. However, since nutrition is not the primary focus of the athletic staff, and many do not possess accurate knowledge (1518), access to a professionally trained nutrition expert such as a registered dietitian may be warranted $(10,14,16,17,19)$.

The fact that athletes rely on the athletic staff for nutritional guidance and that time and accessibility to nutritious foods is a concern for many athletes; the training table, which is a meal provided to athletes by the athletic staff, may be a viable option for nutrition education and dietary intervention of collegiate football players. Providing nutrition education while athletes are consuming meals may be an efficient and effective means of communicating nutritional information and influencing healthy behaviors. To our knowledge, the only study (20) utilizing the training table for nutrition intervention is almost two decades old. Furthermore, since no details on methodology and statistical significance were presented, it is difficult to determine the impact of the intervention. Therefore, the purpose of the present study was to evaluate the effectiveness of training table based nutrition education and menu modification on the nutrition knowledge and dietary intake of collegiate football players at a NCAA Division I university. It was hypothesized that at the end of the study, participants receiving 
nutrition education will have increased nutrition knowledge and higher intake of fruit, vegetables, and low-fat dairy at the training table meals.

\section{METHODS}

\section{Setting}

The study was conducted at the athletic dining facility of San José State University, San José, California during a spring practice season. The training table served as an after practice lunch meal. It was available to all football players on a scholarship (90 players) while those not on a scholarship (10 players) were eligible to eat at the training table upon payment but none elected to do so.

\section{Participants}

The study was introduced to the football team by their head strength and conditioning coach. Players were informed that the study would evaluate their training table meal and they would have access to a nutrition graduate student for nutrition information. It was emphasized that participation was voluntary and would in no way effect their standing with the team.

Initially, 13 football players volunteered to participate in the study. However, final data analysis was done for 12 participants because one participant excluded himself from the study citing personal reasons. Participants represented a variety of offensive and defensive positions on the team. Nine of the 12 participants received nutrition education (detailed below) while three participants opted out of receiving nutrition education and were designated as self-selected controls. The mean ( \pm standard deviation) self-reported age, weight, height and BMI of the intervention group was $20.1 \pm 1.0$ years, 
$111.0 \pm 15.4 \mathrm{~kg}, 189.1 \pm 7.9 \mathrm{~cm}$, and $31.8 \pm 2.4 \mathrm{~kg} / \mathrm{m}^{2}$. The control group characteristics were $20.0 \pm 0$ years, $93.6 \pm 11.6 \mathrm{~kg}, 182.9 \pm 5.5 \mathrm{~cm}$ and $27.9 \pm 2.6 \mathrm{~kg} / \mathrm{m}^{2}$. Participants in the intervention group identified themselves as African-American, Caucasian, or Caucasian-Filipino while those in the control group identified themselves as AfricanAmerican or Caucasian. Written consent was obtained from all participants and the study protocol was approved by the Institutional Review Board of San José State University, San José, California.

\section{Training Table Design}

The training table at San José State University was exclusively available to the football team and was managed by a contracted institutional food vendor. During the regular competitive season, the training table was typically available five days per week. However, during the spring practice season, it was available to all team members for three days per week as an after-practice lunch meal served around noon. It consisted of a salad bar, a hot item buffet which typically served a meat entrée, one or two grain items, one or two vegetables, and a drink station. Players served themselves and were allowed unrestricted servings.

\section{Data Collection}

Data collection was conducted during the spring practice season so any potential changes to the team's eating practices could be implemented prior to the fall competition season. Data were collected over the last three weeks of the 5-week practice season and were divided into baseline, nutrition education, and combination periods. During the baseline period, food intake was measured but no other intervention was provided. 
During the nutrition education period, food intake was measured and a 1-hour, group nutrition education session was provided. During the combination period, the training table menu was modified to include fresh fruit and $1 \%$ chocolate milk, food intake was measured, and nutrition education was continued. Nutrition knowledge was assessed using an 11-point questionnaire at the beginning and end of the study (21). Details on measuring food intake and nutrition education are provided in subsequent sections. The study timeline is outlined in Figure 1. 


\begin{tabular}{|c|c|c|c|c|c|c|c|c|c|c|c|c|}
\hline \multicolumn{13}{|c|}{ Baseline } \\
\hline & $\mathrm{F}$ & $\mathrm{S}$ & $\mathrm{S}$ & $\mathrm{M}$ & $\mathrm{T}$ & $\mathrm{W}$ & $\mathrm{T}$ & $\mathrm{F}$ & $S$ & $\mathrm{~S}$ & & \\
\hline $\begin{array}{c}\text { Nutrition } \\
\text { Knowledge } \\
\text { Questionnaire }\end{array}$ & $\mathrm{X}$ & & & & & & & & & & & \\
\hline $\begin{array}{c}\text { Food Intake } \\
\text { Analysis }\end{array}$ & & & & & & & $\mathrm{X}$ & $\mathrm{X}$ & & & & \\
\hline $\begin{array}{l}\text { Nutrition } \\
\text { Education }\end{array}$ & & & & & & & & & & & & \\
\hline \multicolumn{13}{|c|}{ Spring Break (1-week) } \\
\hline \multicolumn{13}{|c|}{ Nutrition Education } \\
\hline & & & & $\mathrm{M}$ & $\mathrm{T}$ & $\mathrm{W}$ & $\mathrm{T}$ & $\mathrm{F}$ & $S$ & $\mathrm{~S}$ & & \\
\hline $\begin{array}{c}\text { Nutrition } \\
\text { Knowledge } \\
\text { Questionnaire }\end{array}$ & & & & & & & & & & & & \\
\hline $\begin{array}{c}\text { Food Intake } \\
\text { Analysis }\end{array}$ & & & & & & & $\mathrm{X}$ & & & & & \\
\hline $\begin{array}{c}\text { Nutrition } \\
\text { Education (1-hour } \\
\text { session) }\end{array}$ & & & & $\mathrm{X}$ & & & $\mathrm{X}$ & & & & & \\
\hline \multicolumn{13}{|c|}{ Combination } \\
\hline & & & & $\mathrm{M}$ & $\mathrm{T}$ & $\mathrm{W}$ & $\mathrm{T}$ & $\mathrm{F}$ & $S$ & $\mathrm{~S}$ & $\mathrm{M}$ & $\mathrm{T}$ \\
\hline $\begin{array}{c}\text { Nutrition } \\
\text { Knowledge } \\
\text { Questionnaire }\end{array}$ & & & & & & & & & & & & $X$ \\
\hline $\begin{array}{c}\text { Food Intake } \\
\text { Analysis }\end{array}$ & & & & & $\mathrm{X}$ & & $\mathrm{X}$ & $\mathrm{X}$ & & & & \\
\hline $\begin{array}{c}\text { Nutrition } \\
\text { Education (Brief } \\
\text { sessions at the } \\
\text { training table) }\end{array}$ & & & & & $\mathrm{X}$ & & $\mathrm{X}$ & $\mathrm{X}$ & & & & \\
\hline
\end{tabular}

Figure 1. Study timeline for a training table based nutrition education and menu modification intervention in collegiate football players at a NCAA Division I university 
Food Intake. Food intake at the training table was analyzed twice (Thursday and Friday) during the baseline period, once (Thursday) during the nutrition education period, and twice during the combination period (Thursday and Friday). There was a 1-week interval between the end of data collection at baseline and the rest of the study when the university was closed for spring break. During the nutrition education period, the training table was offered for one less day due to changes in the team's activity schedule.

During the baseline period, food intake was recorded by observers who counted portions taken the by subjects as they served themselves. The total weight of the plated food was noted along with a photograph. Plates were weighed in grams on a commercially available kitchen scale (Taylor Precision Products, Oak Brook, IL). Servings of individual food components were then estimated by comparing them to a sample plate. The weight and photograph of any leftover food was also recorded and accounted for in the final data analysis. Due to increased personnel availability, food intake during the nutrition education and combination periods was collected by recording the individual weight of each food component. A total plate weight was also recorded along with a picture and any leftovers were also weighed and accounted for in the final data analysis.

Nutrition Knowledge. Nutrition knowledge of the athletes was assessed at baseline and at the end of the study using a previously validated, self-administered, 11point questionnaire (21). The questionnaire addressed several themes related to sports nutrition including the role of macro- and micro-nutrients, supplements and hydration. Due to ambiguity in the wording of a hydration-related question, it was altered from 
"Sports drinks are better than water" to "Sports drinks are always better than water." Final data analysis for nutrition knowledge was done on eight of the nine intervention group participants who received nutrition education (due to one participant being lost to follow up) and all three control group participants.

Menu Modification. Changes to the training table menu were made in collaboration with the contracted food vendor. It was recommended that the training table offer fresh fruit and a low-fat dairy product. The recommended changes were within the budgetary allotment for the team and did not incur extra costs. They were implemented by the food vendor by offering a fresh fruit salad, bananas, and $1 \%$ chocolate milk during the combination period.

Nutrition Education. Nine participants attended a 1-hour group session outside of the training table setting where topics of general and performance-related nutrition were discussed. The lead investigator conducted the education in a relaxed atmosphere using a guided discussion format. Discussion topics were introduced, participants provided their opinions, voiced concerns, and then evidence-based nutrition information was provided. Topics discussed included: the role of macro- and micro-nutrients in the body, food sources of these nutrients, timing of intake with respect to physical activity, maintaining a healthy body weight, safety of supplements, and hydration. In order for the athletes to apply this information, food options at the training table were identified and participants were instructed on choosing foods that would be ideal for their performance and health goals. Nutrition education was reinforced at the training table in a similar group discussion format for the remainder of the study. Nine participants received 
nutrition education while three participants did not attend the initial nutrition education session and were not given any subsequent nutrition education at the training table.

\section{Statistical Analyses}

Data analysis for food intake was conducted for two days during the baseline period, one day for the nutrition education period and for two days during the combination period. The Wilcoxon signed rank test was used to analyze pre- and posteducation nutrition knowledge scores and intake of cumulative and individual food items (meat, grains, vegetables, salad bar items, fruit, and beverages). Statistical significance was set at $P<0.05$, and data were analyzed using SPSS for Windows (version 20.0, 2012, SPSS Inc., Chicago, IL). Data were expressed as mean \pm standard deviation.

\section{RESULTS AND DISCUSSION}

\section{Change in Nutrition Knowledge}

Compared to baseline, at the end of the study, the intervention group ( $\mathrm{n}=8)$ had statistically significant increased overall, macro- and micro-nutrient-related nutrition knowledge (Table 1). At baseline, all eight participants incorrectly believed that vitamin and mineral supplements increased energy levels whereas at the end of the study only one participant incorrectly identified the role of vitamins and minerals. At baseline, only three out of eight (38\%) participants correctly identified that protein was not the main energy source for muscles and the same number believed that protein supplements were necessary. At the end of the study, five out of eight participants (63\%) correctly identified that protein was not the main energy source for muscles and seven out of eight $(88 \%)$ participants correctly responded that protein supplements were not necessary. 
Regarding the role of carbohydrates and fats, at baseline, six out of eight (75\%) participants correctly identified that carbohydrates and fat were main energy sources. At the end of the study, all eight participants correctly responded that carbohydrates and fats were the main energy sources. Even though all participants correctly identified the role of carbohydrates and fats upon post-test, three out of eight subjects still believed that protein was the main energy source for muscles. The results indicate that this subset of football players did not have complete knowledge regarding the role of macro-nutrients for performance and that nutrition education improved their understanding. The fact that three of the eight participants continued to believe that protein was the main energy source for muscles may suggest that despite continued nutrition education over a short period of time, many athletes may not be able to overcome previous nutrition-related misconceptions.

Athletes in the intervention group had no statistically significant improvement in knowledge scores regarding hydration. This was due to preexisting accurate knowledge in that area since nearly all subjects correctly answered all four (100\%) hydration-related questions at baseline. These results indicate that this subset of football players were aware of strategies for detecting thirst, fluid replenishment and the negative effect of dehydration on performance.

Similar to the intervention group, the control group scored high on hydrationrelated questions and had incorrect information regarding the role of macro- and micronutrients at baseline. Unlike the intervention group, the control group $(n=3)$ 
demonstrated no statistically significant difference in nutrition knowledge scores at the end of the 3-week study (Table 1).

In summary, the subjects lacked basic knowledge regarding the role of macroand micro-nutrients in the body, and efficacy of supplements, but had adequate information regarding strategies for detecting thirst, fluid replenishment, and the negative effect of dehydration on performance at baseline. Lack of basic nutritional knowledge may have profound implications on food choices, performance, and overall health of athletes. Overall, the change in nutrition knowledge scores indicated that nutrition education delivered in a small group setting and reinforced at the training table meal significantly increased the nutrition knowledge scores of collegiate football players $(P=$ $0.018)$. 
Table 1. Nutrition knowledge scores of collegiate football players at a Division I university pre- and post-study

\begin{tabular}{|c|c|c|c|c|}
\hline $\begin{array}{l}\text { Intervention } \\
\text { Group }(n=8)\end{array}$ & $\begin{array}{l}\text { Knowledge } \\
\text { Component }\end{array}$ & Pre-Study & Post-Study & $\begin{array}{c}P \\
\text { Values }\end{array}$ \\
\hline & $\begin{array}{l}\text { Overall Mean Score } \\
\quad(\text { Out of } 11)\end{array}$ & $7.63 \pm 1.69$ & $10.13 \pm 0.84^{\mathrm{a}}$ & 0.018 \\
\hline & $\begin{array}{l}\text { Macro-nutrient } \\
\text { Score (Out of 6) }\end{array}$ & $3.25 \pm 1.39$ & $5.25 \pm 0.71^{\mathrm{a}}$ & 0.041 \\
\hline & $\begin{array}{c}\text { Micro-nutrient Score } \\
\text { (Out of } 1)\end{array}$ & $0.00 \pm 0.00$ & $0.88 \pm 0.35^{\mathrm{a}}$ & 0.008 \\
\hline & $\begin{array}{l}\text { Hydration Score } \\
\text { (Out of } 4)\end{array}$ & $3.88 \pm 0.35$ & $4.00 \pm 0.00$ & 0.317 \\
\hline \multirow[t]{4}{*}{$\begin{array}{c}\text { Control } \\
\text { Group }(n=3)\end{array}$} & $\begin{array}{c}\text { Overall Mean Score } \\
(\text { Out of } 11)\end{array}$ & $8.67 \pm 0.58$ & $7.00 \pm 1.73$ & 0.180 \\
\hline & $\begin{array}{l}\text { Macro-nutrient } \\
\text { Score (Out of 6) }\end{array}$ & $4.33 \pm 0.58$ & $3.33 \pm 1.16$ & 0.317 \\
\hline & $\begin{array}{c}\text { Micro-nutrient Score } \\
\text { (Out of 1) }\end{array}$ & $0.33 \pm 0.58$ & $0.00 \pm 0.00$ & 0.317 \\
\hline & $\begin{array}{l}\text { Hydration Score } \\
\text { (Out of } 4)\end{array}$ & $4.00 \pm 0.00$ & $3.67 \pm 0.58$ & 0.317 \\
\hline
\end{tabular}

${ }^{a}$ Score significantly higher compared to pre-study 


\section{Change in Food Intake}

Mean intake data for food and beverages consumed during the three study periods is detailed in Table 2. For the intervention group, mean total food and beverage intake was significantly increased during the combination period when compared to baseline. Intake was increased due to the consumption of fresh fruit salad, bananas and $1 \%$ chocolate milk. The introduction of fresh fruit did not change the overall intake of fruits and vegetables, but as indicated by a statistically significant decreased intake of vegetables and items from the salad bar during the combination period, it appears that the athletes opted to consume fresh fruit instead of vegetables. This may suggest greater preference or familiarity with fruits rather than vegetables among these athletes.

Among the self-selected control group, there were no statistically significant differences in intake across any of the study periods for any food items even when fresh fruit and $1 \%$ chocolate milk were offered. Due to the small number of subjects in the control group, it is possible that some changes in intake may not have reached statistical significance.

An interesting trend that was observed for both the intervention and control groups was that the highest consumption of meat and the lowest consumption of grains was recorded during the nutrition education treatment period. Based on observations at the training table, this was most likely due to the fact that the only grain and meat served that day were hamburger buns with pulled pork. On other days, the athletes had a greater variety of grains such as rice and pasta, possibly resulting in higher grain consumption. Additionally, the players reported severely disliking the vegetables served that day 
(glazed carrots and sweet potatoes) which remained essentially untouched by a majority of the players. Differences in the preference for specific menu items served, highlights the real-world application of this research; that nutrition education of athletes is only one part of promoting healthy dietary behaviors. Since the athletic staff or their contracted vendors are responsible for providing training tables at many institutions and many do not possess the appropriate knowledge, professionals such as registered dietitians who are competent in providing nutrition education and managing food service may better serve the nutritional needs of the athletes. 
Table 2. Food and beverage intake of collegiate football players at a NCAA Division I university at baseline (B), nutrition education (NE) and combination (C) periods

\begin{tabular}{|c|c|c|c|c|c|c|}
\hline $\begin{array}{c}\text { Food Component } \\
\text { (Intervention Group } \\
\mathbf{n = 9})\end{array}$ & Baseline (g) & $\begin{array}{c}\text { Nutrition } \\
\text { Education (g) }\end{array}$ & $\begin{array}{c}P \text { Value } \\
(\mathrm{B}-\mathrm{NE})\end{array}$ & Combination (g) & $\begin{array}{c}P \\
\text { Value } \\
\text { (B-C) }\end{array}$ & $\begin{array}{c}P \\
\text { Value } \\
(\text { NE-C) }\end{array}$ \\
\hline \multirow[t]{4}{*}{$\begin{array}{c}\text { Mean Total Food \& } \\
\text { Beverage }\end{array}$} & \multirow[t]{4}{*}{$686.3 \pm 213.1$} & \multirow[t]{4}{*}{$1002.4 \pm 353.6^{\mathrm{a}}$} & \multirow[t]{4}{*}{0.038} & $\begin{array}{c}1296.4 \pm 413 \text { (w fruit, } \mathrm{w} \\
\text { milk) }^{\mathrm{a}}\end{array}$ & 0.008 & 0.314 \\
\hline & & & & $\begin{array}{c}750 \pm 289.8 \text { (w/o fruit, w/o } \\
\text { milk) }\end{array}$ & 0.314 & 0.110 \\
\hline & & & & $\begin{array}{c}1155.9 \pm 353.3(\text { w/o fruit } \\
\text { w milk) }\end{array}$ & 0.021 & 0.515 \\
\hline & & & & $\begin{array}{c}890.0 \pm 355.4(\mathrm{w} \text { fruit, w/o } \\
\text { milk) })^{\mathrm{a}}\end{array}$ & 0.086 & 0.441 \\
\hline \multirow[t]{2}{*}{ Mean Total Food } & $512.7 \pm 113.7$ & $558.0 \pm 181.4$ & 0.441 & 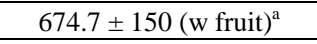 & 0.021 & 0.214 \\
\hline & & & & $534.2 \pm 135.2$ (w/o fruit) & 0.374 & 0.594 \\
\hline Meat & $164.8 \pm 37.7$ & $263.1 \pm 66.1^{\mathrm{a}}$ & 0.011 & $175.7 \pm 61.6$ & 0.594 & 0.051 \\
\hline Grains & $140.7 \pm 116.4$ & $85.89 \pm 47.0$ & 0.093 & $221.7 \pm 116.4^{b}$ & 0.086 & 0.011 \\
\hline Vegetables & $166.2 \pm 62.4$ & $148.7 \pm 122.6$ & 0.514 & $117.6 \pm 62.0$ & 0.110 & 0.594 \\
\hline Salad Bar & $40.2 \pm 48.0$ & $60.3 \pm 111.3$ & 0.715 & $19.3 \pm 25.1$ & 0.173 & 0.600 \\
\hline Vegetables \& Salad Bar & $206.3 \pm 46.0$ & $209.0 \pm 179.1$ & 0.953 & $277.4 \pm 105.8$ (w fruit) & 0.173 & 0.260 \\
\hline \multicolumn{4}{|l|}{ 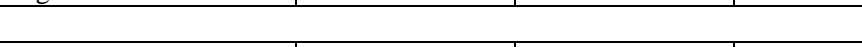 } & $136.9 \pm 64.3$ (w/o fruit) ${ }^{\mathrm{a}}$ & 0.011 & 0.214 \\
\hline Fresh Fruit & - & - & - & $140.5 \pm 133.0$ & - & - \\
\hline \multirow{2}{*}{ Mean Total Beverages } & $173.6 \pm 181.6$ & $444.4 \pm 300.5^{\mathrm{a}}$ & 0.027 & $621.7 \pm 366.5(\mathrm{w} \text { milk })^{\mathrm{a}}$ & 0.028 & 0.312 \\
\hline & & & & $215.3 \pm 295.0$ (w/o milk) & 0.893 & 0.072 \\
\hline Sports Drink & $145.8 \pm 139.8$ & $388.9 \pm 333.3^{\mathrm{a}}$ & 0.026 & $215.3 \pm 295.0$ & 0.786 & 0.136 \\
\hline Fruit Juice & $55.6 \pm 166.7$ & $55.6 \pm 166.7$ & 1.000 & $0.0 \pm 0.0$ & 0.317 & 0.317 \\
\hline Flavored Milk & - & - & - & $406.4 \pm 157.3$ & - & - \\
\hline $\begin{array}{c}\text { Food Component } \\
(\text { Control Group } n=3)\end{array}$ & Baseline (g) & $\begin{array}{c}\text { Nutrition } \\
\text { Education (g) }\end{array}$ & $\begin{array}{c}P \text { Value } \\
\text { (B-NE) }\end{array}$ & Combination (g) & $\begin{array}{c}P \\
\text { Value } \\
\text { (B-C) }\end{array}$ & $\begin{array}{c}P \\
\text { Value } \\
(\text { NE-C) }\end{array}$ \\
\hline \multirow[t]{4}{*}{$\begin{array}{c}\text { Mean Total Food \& } \\
\text { Beverage }\end{array}$} & \multirow[t]{4}{*}{$1091.5 \pm 642.3$} & \multirow[t]{4}{*}{$1130.0 \pm 721.7$} & \multirow[t]{4}{*}{0.593} & $\begin{array}{c}1404.7 \pm 631.2 \text { (w fruit, } w \\
\text { milk) }\end{array}$ & 0.109 & 0.109 \\
\hline & & & & $\begin{array}{c}820.3 \pm 354.0 \text { (w/o fruit, } \\
\text { w/o milk) }\end{array}$ & 0.285 & 0.285 \\
\hline & & & & $\begin{array}{c}1331.7 \pm 721.2 \text { (w/o fruit, } \\
\text { w milk) }\end{array}$ & 0.109 & 0.109 \\
\hline & & & & $\begin{array}{c}893.3 \pm 252.8 \text { (w fruit, } \\
\text { w/o milk) }\end{array}$ & 0.285 & 0.593 \\
\hline \multirow[t]{2}{*}{ Mean Total Food } & $820.7 \pm 361.2$ & $630.0 \pm 229.8$ & 0.285 & $628.2 \pm 90.8$ (w fruit) & 0.285 & 1.000 \\
\hline & & & & \pm (w/o fruit) & & \\
\hline Meat & $196.5 \pm 36.1$ & $208.3 \pm 68.4$ & 0.593 & $126.7 \pm 50.0$ & 0.109 & 0.109 \\
\hline Grains & $189.0 \pm 81.0$ & $72.0 \pm 32.1$ & 0.109 & $264.2 \pm 108.4$ & 0.285 & 0.109 \\
\hline Vegetables & $240.0 \pm 185.8$ & $228.3 \pm 105.6$ & 1.000 & $136.5 \pm 47.1$ & 0.593 & 0.109 \\
\hline Salad Bar & $145.8 \pm 50.1$ & $121.3 \pm 116.8$ & 1.000 & $27.8 \pm 41.9$ & 0.109 & 0.285 \\
\hline \multirow[t]{2}{*}{ Vegetables \& Salad Bar } & \multirow[t]{2}{*}{$385.8 \pm 187.1$} & \multirow[t]{2}{*}{$349.7 \pm 130.9$} & \multirow[t]{2}{*}{0.285} & $237.3 \pm 143.5 \quad$ (w fruit) & 0.414 & 0.593 \\
\hline & & & & $164.3 \pm 41.4$ (w/o fruit) & 0.109 & 0.109 \\
\hline Fresh Fruit & - & - & - & $73.0 \pm 126.4$ & - & - \\
\hline \multirow[t]{2}{*}{ Mean Total Beverages } & $270.8 \pm 281.8$ & $500.0 \pm 500.0$ & 0.180 & $776.5 \pm 613.9(\mathrm{w}$ milk $)$ & 0.109 & 0.109 \\
\hline & & & & $265.2 \pm 251.4$ (w/o milk) & 0.655 & 0.180 \\
\hline Sports Drink & $270.8 \pm 281.8$ & $500.0 \pm 500.0$ & 0.180 & $265.2 \pm 251.4$ & 0.655 & 0.180 \\
\hline Fruit Juice & $0.0 \pm 0.00$ & $0.0 \pm 0.00$ & 1.000 & $0.0 \pm 0.00$ & 1.000 & 1.000 \\
\hline Flavored Milk & - & - & - & $511.3 \pm 379.3$ & - & - \\
\hline
\end{tabular}

${ }^{\mathrm{a}}$ Intake significant compared to baseline, ${ }^{\mathrm{b}}$ Intake significant compared to nutrition education 


\section{Change in Beverage Intake}

Compared to baseline, beverage intake for the intervention group was significantly increased in the nutrition education period due to increased consumption of the sports beverage. This increase may be a result of the nutrition education received regarding the benefits of a post-workout sports beverage. In the combination period, beverage intake was significantly increased than baseline only when $1 \%$ chocolate milk was made available. During that time, participants completely eliminated their intake of grape juice and opted to consume $1 \%$ chocolate milk and sports beverage leading to the overall increased beverage intake.

In the control group, there were no statistically significant differences in beverage intake for any of the study periods. However, all three participants consumed the $1 \%$ chocolate milk when it was offered indicating that it was well-accepted regardless of nutrition education.

In summary, a training table based intervention such as this one that provides nutrition education to the athletes and modifies the menu to include well-liked, nutrientdense food items may be an effective way of promoting positive dietary choices.

\section{Limitations}

This pilot study was designed to evaluate dietary habits of collegiate football players within the practical setting of a college training table over a brief 3 -week period. Since different menu items were served each day, pre-existing food preferences may have influenced food choices regardless of the nutrition education delivered. Since the training table was served as an after-practice meal, differences in the intensity of practice 
and the weather may have influenced consumption of food and beverages on any particular day. The small number of participants in the overall study and in the selfselected control group may have resulted in failure to reach statistical significance for nutrition knowledge scores and food intake. Finally, data during the nutrition education period was analyzed for one day; thus, limiting the conclusions that could be reached for the effect of nutrition education alone.

\section{Practical Implications}

The strength of this pilot study lies in the many practical implications of the results which can be readily applied in a training table setting. Providing nutrition education in a guided discussion format may improve the nutrition knowledge of athletes and may positively impact food choices. It is also reasonable to assume that this knowledge may be applied to food choices beyond the training table. Furthermore, addition of simple, inexpensive, and nutrient-dense foods such as fresh fruit and low-fat dairy to the training table may also improve the dietary choices of athletes without increasing the operating cost of the program. Since these changes successfully improved the nutrition knowledge and dietary intake in an ethnically diverse subset of football players, it is reasonable to assume that they are applicable to other institutions and populations as well. Therefore, the training table may be an important avenue for improving the nutrition knowledge and dietary intake of intercollegiate athletes.

Although not part of the present study, anecdotal experience indicated that some non-study football players and staff members regularly asked the research team questions about appropriate food choices and performance-related nutrition, indicating a general 
interest in improving their knowledge and understanding of nutrition. Additionally, nonstudy participants also consumed the fresh fruit and low-fat dairy served at the training table, indicating that serving familiar, nutrient-dense foods may encourage intake of those items. Therefore, the communal setting of a training table meal may be an avenue for improving the nutrition knowledge and dietary intake of entire collegiate teams.

\section{CONCLUSIONS}

Many collegiate football players lack basic nutritional knowledge of adequate dietary practices for maintaining their health and performance. For many athletes, time and accessibility to nutritious foods is a further limitation to optimal dietary choices. Therefore, nutrition education and support is strongly recommended in this population. An intervention such as the one presented, provides nutrition education and appropriate food choices without requiring extra monetary resources and requires minimal extra time. Thus, training table-based intervention and nutrition education may be a viable option for positively influencing the dietary behavior of collegiate athletes.

Future work in the area can use the same intervention strategy for different collegiate or professional teams that are offered a training table, at other meals provided by the athletic staff or over a longer period of time. Additional work can also evaluate

the impact of nutritional changes on performance by analyzing changes in strength, body fat percentage, hydration status, frequency of muscle cramps and other performancerelated measures. 


\section{References}

1. National Collegiate Athletic Association, Football Attendance Records. (n.d.). Retrieved from http://fs.ncaa.org/Docs/stats/football_records/2012/attend.pdf

2. Cole, C. R., Salvaterra, G. F., Davis, J. E., Jr., Borja, M. E., Powell, L. M., Dubbs, E. C., \& Bordi, P. L. (2005). Evaluation of dietary practices of National Collegiate Athletic Association division I football players. Journal of Strength and Conditioning Research, 19, 490-494. doi: 10.1519/14313.1

3. Jonnalagadda, S. S., Rosenbloom, C. A., \& Skinner, R. (2001). Dietary practices, attitudes, and physiological status of collegiate freshman football players. Journal of Strength and Conditioning Research, 15, 507-513.

4. Kirwan, R. D., Kordick, L. K., McFarland, S., Lancaster, D., Clark, K., \& Miles, M. P. (2012). Dietary, anthropometric, blood-lipid, and performance patterns of American college football players during 8 weeks of training. International Journal of Sport Nutrition and Exercise Metabolism, 22, 444-451.

5. Jacobson, B. H. (2012). Anthropometric cross-sectional comparisons of college football players and potential health implications. Journal of Strength and Conditioning Research, 26(12), 3358-3364. doi: 10.1519/JSC.0b013e31824b5e6c

6. Anzell, A. R., Potteiger, J. A., Kraemer, W. J., \& Otieno, S. (2013). Changes in height, body weight, and body composition in American football players from 1942 to 2011. Journal of Strength and Conditioning Research, 27(2), 277-284. doi: 10.1519/JSC.0b013e31827f4c08; 10.1519/JSC.0b013e31827f4c08

7. Kaiser, G. E., Womack, J. W., Green, J. S., Pollard, B., Miller, G. S., \& Crouse, S. F. (2008). Morphological profiles for first-year National Collegiate Athletic Association division I football players. Journal of Strength and Conditioning Research, 22(1), 243249. doi: 10.1519/JSC.0b013e31815f5d97

8. Buell, J. L., Calland, D., Hanks, F., Johnston, B., Pester, B., Sweeney, R., \& Thorne, R. (2008). Presence of metabolic syndrome in football linemen. Journal of Athletic Training, 43(6), 608-616. doi: 10.4085/1062-6050-43.6.608; 10.4085/1062-605043.6.608

9. Wilkerson, G. B., Bullard, J. T., \& Bartal, D. W. (2010). Identification of cardiometabolic risk among collegiate football players. Journal of Athletic Training, 45(1), 67-74. doi: 10.4085/1062-6050-45.1.67; 10.4085/1062-6050-45.1.67 
10. Heaney, S., O’Connor, H., Naughton, G., \& Gifford, J. (2008). Towards an understanding of the barriers to good nutrition for elite athletes. International Journal of Sports Science \& Coaching, 3(3), 391-401.

11. Long, D., Perry, C., Unruh, S. A., Lewis, N., \& Stanek-Krogstrand, K. (2011). Personal food systems of male collegiate football players: A grounded theory investigation. Journal of Athletic Training, 46(6), 688-695.

12. Parr, R. B., Porter, M. A., \& Hodgson, S. C. (1984). Nutrition knowledge and practice of coaches, trainers, and athletes. The Physician and sportsmedicine, 12(3), 126-128, 133134, 137-138.

13. Jacobson, B. H., Sobonya, C., \& Ransone, J. (2001). Nutrition practices and knowledge of college varsity athletes: A follow-up. Journal of Strength and Conditioning Research, 15(1), 63-68.

14. Burns, R. D., Schiller, M. R., Merrick, M. A., \& Wolf, K. N. (2004). Intercollegiate student athlete use of nutritional supplements and the role of athletic trainers and dietitians in nutrition counseling. Journal of the American Dietetic Association, 104(2), 246-249. doi: 10.1016/j.jada.2003.11.013

15. Corley, G., Demarest-Litchford, M., \& Bazzarre, T. L. (1990). Nutrition knowledge and dietary practices of college coaches. Journal of the American Dietetic Association, 90(5), 705-709.

16. Torres-McGehee, T. M., Pritchett, K. L., Zippel, D., Minton, D. M., Cellamare, A., \& Sibilia, M. (2012). Sports nutrition knowledge among collegiate athletes, coaches, athletic trainers, and strength and conditioning specialists. Journal of Athletic Training, 47(2), 205-211.

17. Smith-Rockwell, M., Nickols-Richardson, S. M., \& Thye, F. W. (2001). Nutrition knowledge, opinions, and practices of coaches and athletic trainers at a division 1 university. International Journal of Sport Nutrition and Exercise Metabolism, 11(2), 174185.

18. Shifflett, B., Timm, C., \& Kahanov, L. (2002). Understanding of athletes' nutritional needs among athletes, coaches, and athletic trainers. Research Quarterly for Exercise and Sport, 73(3), 357-362.

19. Quatromoni, P. A. (2008). Clinical observations from nutrition services in college athletics. Journal of the American Dietetic Association, 108(4), 689-694. doi: 10.1016/j.jada.2008.01.008; 10.1016/j.jada.2008.01.008 
20. Clark, K. L. (1994). Working with college athletes, coaches and trainers at a major university. International Journal of Sport Nutrition, 4, 135-141.

21. Rosenbloom, C. A., Jonnalagadda, S. S., \& Skinner, R. (2002). Nutrition knowledge of collegiate athletes in a division I National Collegiate Athletic Association institution. Journal of the American Dietetic Association, 102(3), 418-420. 
CHAPTER III

SUMMARY AND REFERENCES 


\section{SUMMARY}

Many collegiate football players lack basic nutritional knowledge of adequate dietary practices for maintaining their health and performance. For many athletes, time and accessibility to nutritious foods is a further limitation to optimal dietary choices. Evidence in the literature also highlights the prevalence of obesity, metabolic syndrome, and cardiovascular risk in collegiate football players. Therefore, nutrition education and support is strongly recommended in this population. An intervention such as the one presented provides nutrition education and appropriate food choices without requiring extra monetary resources and requires minimal extra time. Thus, training table-based intervention and nutrition education may be a viable option for positively influencing the dietary behavior of collegiate athletes. 


\section{References}

American College of Sports Medicine, American Dietetic Association, \& Dietitians of Canada. (2000). Joint position statement: Nutrition and athletic performance. American College of Sports Medicine, American Dietetic Association, and Dietitians of Canada. Medicine and Science in Sports and Exercise, 32(12), 2130-2145.

Anzell, A. R., Potteiger, J. A., Kraemer, W. J., \& Otieno, S. (2013). Changes in height, body weight, and body composition in American football players from 1942 to 2011. Journal of Strength and Conditioning Research, 27(2), 277-284. doi: 10.1519/JSC.0b013e31827f4c08; 10.1519/JSC.0b013e31827f4c08

Baron, S. L., Hein, M. J., Lehman, E., \& Gersic, C. M. (2012). Body mass index, playing position, race, and the cardiovascular mortality of retired professional football players. The American Journal of Cardiology, 109(6), 889-896. doi:

10.1016/j.amjcard.2011.10.050

Bonci, L. J. (2011). Eating for performance: Bringing science to the training table. Clinics in Sports Medicine, 30(3), 661-670. doi: 10.1016/j.csm.2011.03.011

Buell, J. L., Calland, D., Hanks, F., Johnston, B., Pester, B., Sweeney, R., \& Thorne, R. (2008). Presence of metabolic syndrome in football linemen. Journal of Athletic Training, 43(6), 608-616. doi: 10.4085/1062-6050-43.6.608; 10.4085/1062-605043.6.608

Burns, R. D., Schiller, M. R., Merrick, M. A., \& Wolf, K. N. (2004). Intercollegiate student athlete use of nutritional supplements and the role of athletic trainers and dietitians in nutrition counseling. Journal of the American Dietetic Association, 104(2), 246-249. doi: 10.1016/j.jada.2003.11.013

Clark, K. L. (1994). Working with college athletes, coaches and trainers at a major university. International Journal of Sport Nutrition, 4, 135-141.

Cole, C. R., Salvaterra, G. F., Davis, J. E., Jr., Borja, M. E., Powell, L. M., Dubbs, E. C., \& Bordi, P. L. (2005). Evaluation of dietary practices of national collegiate athletic association division I football players. Journal of Strength and Conditioning Research, 19(3), 490-494. doi: 10.1519/14313.1

Corley, G., Demarest-Litchford, M., \& Bazzarre, T. L. (1990). Nutrition knowledge and dietary practices of college coaches. Journal of the American Dietetic Association, 90(5), 705-709. 
Fulks, D. L. (2012). Revenue \& expenses, NCAA Division I intercollegiate athletics programs report. Retrieved from NCAA website:

http://www.ncaapublications.com/productdownloads/D12011REVEXP.pdf

Heaney, S., O’Connor, H., Naughton, G., \& Gifford, J. (2008). Towards an understanding of the barriers to good nutrition for elite athletes. International Journal of Sports Science \& Coaching, 3(3), 391-401.

Hoffman, J. R. (2008). The applied physiology of American football. International Journal of Sports Physiology and Performance, 3(3), 387-392.

Jacobson, B. H. (2012). Anthropometric cross-sectional comparisons of college football players and potential health implications. Journal of Strength and Conditioning Research, 26(12), 3358-3364. doi: 10.1519/JSC.0b013e31824b5e6c

Jacobson, B. H., Sobonya, C., \& Ransone, J. (2001). Nutrition practices and knowledge of college varsity athletes: A follow-up. Journal of Strength and Conditioning Research, 15(1), 63-68.

Jonnalagadda, S. S., Rosenbloom, C. A., \& Skinner, R. (2001). Dietary practices, attitudes, and physiological status of collegiate freshman football players. Journal of Strength and Conditioning Research, 15(4), 507-513.

Kaiser, G. E., Womack, J. W., Green, J. S., Pollard, B., Miller, G. S., \& Crouse, S. F. (2008). Morphological profiles for first-year national collegiate athletic association division I football players. Journal of Strength and Conditioning Research, 22(1), 243249. doi: 10.1519/JSC.0b013e31815f5d97

Kirwan, R. D., Kordick, L. K., McFarland, S., Lancaster, D., Clark, K., \& Miles, M. P. (2012). Dietary, anthropometric, blood-lipid, and performance patterns of American college football players during 8 weeks of training. International Journal of Sport Nutrition and Exercise Metabolism, 22(6), 444-451.

Kraemer, W. J., Torine, J. C., Silvestre, R., French, D. N., Ratamess, N. A., Spiering, B. A., ... Volek, J. S. (2005). Body size and composition of National Football League players. Journal of Strength and Conditioning Research, 19(3), 485-489. doi:

$10.1519 / 18175.1$

Long, D., Perry, C., Unruh, S. A., Lewis, N., \& Stanek-Krogstrand, K., (2011). Personal food systems of male collegiate football players: A grounded theory investigation.

Journal of Athletic Training, 46(6), 688-695. 
National Collegiate Athletic Association. (n.d.). Retrieved from

http://www.ncaa.org/wps/wcm/connect/public/ncaa/finances/index.html

National Collegiate Athletic Association, Football Attendance Records. (n.d.). Retrieved from http://fs.ncaa.org/Docs/stats/football_records/2012/attend.pdf

Parr, R. B., Porter, M. A., \& Hodgson, S. C. (1984). Nutrition knowledge and practice of coaches, trainers, and athletes. The Physician and sportsmedicine, 12(3), 126-128, 133134, 137-138.

Quatromoni, P. A. (2008). Clinical observations from nutrition services in college athletics. Journal of the American Dietetic Association, 108(4), 689-694. doi: 10.1016/j.jada.2008.01.008; 10.1016/j.jada.2008.01.008

Rosenbloom, C. A., Jonnalagadda, S. S., \& Skinner, R. (2002). Nutrition knowledge of collegiate athletes in a division I National Collegiate Athletic Association institution. Journal of the American Dietetic Association, 102(3), 418-420.

Shifflett, B., Timm, C., \& Kahanov, L. (2002). Understanding of athletes' nutritional needs among athletes, coaches, and athletic trainers. Research Quarterly for Exercise and Sport, 73(3), 357-362.

Smith-Rockwell, M., Nickols-Richardson, S. M., \& Thye, F. W. (2001). Nutrition knowledge, opinions, and practices of coaches and athletic trainers at a division 1 university. International Journal of Sport Nutrition and Exercise Metabolism, 11(2), 174185.

Torres-McGehee, T. M., Pritchett, K. L., Zippel, D., Minton, D. M., Cellamare, A., \& Sibilia, M. (2012). Sports nutrition knowledge among collegiate athletes, coaches, athletic trainers, and strength and conditioning specialists. Journal of Athletic Training, 47(2), 205-211.

Vinci, D. M. (1998). Effective nutrition support programs for college athletes. International Journal of Sport Nutrition, 8(3), 308-320.

Wilkerson, G. B., Bullard, J. T., \& Bartal, D. W. (2010). Identification of cardiometabolic risk among collegiate football players. Journal of Athletic Training, 45(1), 67-74. doi: 10.4085/1062-6050-45.1.67; 10.4085/1062-6050-45.1.67 


\section{APPENDIX A}

\section{Food Knowledge Questionnaire}

Date:

Participant Code:

For each of the statements below, please circle the answer you think it most appropriate. If you do not lnow an answer, circle "Don't Know" instead of guessing the answer.

1. Carbohydrate and fat are the main energy sources

2. Should not eat sweets prior to an event

3. Eating carbohydrates makes you fat

4. Should consume high-fat meals 2 to 3 hours before an event

5. Protein is the main energy source for the muscle

6. Protein supplements are necessary

7. Should replace fluids before, during and after an event

8. Sports drinks are always better than water

9. Should rely on thirst to ensure fluid replacement

10. Dehydration decreases performance

11. Vitamin and mineral supplements increase energy

$\begin{array}{lll}\text { Agree } & \text { Disagree } & \text { Don't Know } \\ \text { Agree } & \text { Disagree } & \text { Don't Know } \\ \text { Agree } & \text { Disagree } & \text { Don't Know } \\ \text { Agree } & \text { Disagree } & \text { Don't Know } \\ \text { Agree } & \text { Disagree } & \text { Don't Know } \\ \text { Agree } & \text { Disagree } & \text { Don't Know } \\ \text { Agree } & \text { Disagree } & \text { Don't Know } \\ \text { Agree } & \text { Disagree } & \text { Don't Know } \\ \text { Agree } & \text { Disagree } & \text { Don't Know } \\ \text { Agree } & \text { Disagree } & \text { Don't Know } \\ \text { Agree } & \text { Disagree } & \text { Don't Know }\end{array}$

\section{Thank you for your participation!}

